\title{
Proses Islamisasi dan Penyebaran Islam di Nusantara
}

\author{
Intan Permatasari ${ }^{1}$, Hudaidah $^{2}$ \\ ${ }^{1,2}$ Universitas Sriwijaya \\ intanpermatasari241001@gmail.com, \\ hudaidah@fkip.unsri.ac.id
}

\begin{abstract}
Abstrak
Proses masuk dan Islamisasi serta penyebaran Islam di Indonesia sering menarik perhatian untuk dipelajari dan diteliti. Terutama di kalangan umat muslim yang berada dalam dunia akademisi. Hal ini terkait dengan beberapa pertanyaan yang sering muncul, pertanyaan itu terkait tentang kapan agama Islam sebenarnya datang? Siapa sebenarnya yang menyebarkan Islam ke Indonesia. Terkait dengan pertanyaan tersebut, tujuan penelitian ini adalah untuk mengetahui teori masuknya Islam dan proses Islamisasi di Indonesia. Metode yang dipakai yaitu metode penelitian kepustakaan. Kesimpulannya bahwa Islami di Indonesia berjalan secara damai. Adapun teori masuknya Islam di Indonesia adalah teori Gujarat, teori Arab, teori Persia, teori Cina. Untuk proses Islamisasi dan penyebaran Islam di Indonesia dilakukan dengan jalur perdagangan, perkawinan, pendidikan, tasawuf, politik, serta seni dan budaya.
\end{abstract}

Kata Kunci: Islamisasi, Islam, Nusantara

\begin{abstract}
The process of entry and Islamization and the spread of Islam in Indonesia often attract attention to be studied and researched. Especially among Muslims who are in the world of academia. This is related to several questions that often arise, the question is related to when did Islam actually come? Who actually spread Islam to Indonesia? Related to this question, the purpose of this study is to find out the theory of the entry of Islam and the process of Islamization in Indonesia. The method used is the library research method. The conclusion is that Islam in Indonesia runs peacefully. The theory of the entry of Islam in Indonesia is the Gujarat theory, the Arabic theory, the Persian theory, the Chinese theory. The process of Islamization and the spread of Islam in Indonesia is carried out through trade, marriage, education, Sufism, politics, and arts and culture.
\end{abstract}

Keywords: Islamization, Islam, Nusantara

Jurnal Humanitas is licensed under a Creative Commons AttributionShareAlike 4.0 International License. 


\section{Pendahuluan}

Terkait kehidupan manusia, apabila dilihat dari segi terminologi fakta sosialnya, menyatakan bahwa agama adalah sebuah fakta historis dan budaya yang ada pada suatu keyakinan yang mutlak yang tak terbantahkan. agama hadir didalam setiap diri dari manusia selama perkembangannya di muka bumi, serta totalitas dari pada kehidupan dari setiap diri manusia berdasarkan keyakinan pada agamanya. Hal ini didasarkan bahwa agama menjadi sebuah sistem nilai yang universal yang ada dalam setiap diri manusia (Lestari, 2019).

Islam adalah agama rahmatan lil 'alamin, kehidupan ini telah diajarkan dan dicontohkan oleh utusan-Nya, yakni Rasulullah SAW. Namun, penyebaran Islam ke berbagai belahan dunia tidaklah berjalan dengan mudah. Namun demikian, ini juga unik terkait dengan proses masuknya Islam ke Nusantara. Keunikan ini bisa dilihat dari prosesnya, lebih spesifiknya dengan perdamaian dan dibawa oleh para pedagang dan mubaligh (Daulay, 2020).

Islam adalah agama dengan penganut nomor dua terbanyak yang ada di dunia. Islam selalu mengajarkan untuk menghormati satu sama lain dan mempunyai toleransi yang sangat tinggi, Islam mengajarkan sikap kasih sayang, peduli kepada orang lain tanpa harus memandang perbedaan yang ada diantara mereka (Astuti, 2017). Ketika Islam memasuki suatu daerah atau kawasan karakteristik dari unsur lokal juga ikut mengalir ke dalam nilainilai yang ada dalam Islam tersebut (Ghofur, 2011).

Islam hadir di Indonesia dengan jalan yang damai dan dengan jiwa toleransi yang tinggi serta saling menghormati di antara penyebar dan pendukung agama baru dan pemeluk agama lama (Hindu-Budha). Islam dipandang sebagai agama yang lebih baik oleh rakyat yang pada awalnya beragama Hindu. Hal ini dengan alasan Islam tidak mempersepsikan kedudukan dan tidak ada perbedaan dalam masyarakatnya (Dalimunthe, 2016). Dari banyaknya negara yang ada di dunia, Indonesia adalah satu di antara negara dengan jumlah penganut Islam terbanyak. Islam menyebar di Indonesia mulai abad ke-7 M dan mulai adanya kemajuan yang luas pada abad ke-13 M (Amrullah, 2015). Suatu proses Islamisasi begitu penting dalam sejarahnya di Indonesia dan juga belum jelas. Hal ini terkait dengan beberapa pertanyaan yang sering muncul, pertanyaan itu terkait tentang kapan agama Islam sebenarnya datang, berasal dari manakah agama islam itu, siapa sebenarnya yang menyebarkan islam ke Indonesia untuk yang pertama kali (Husda, 2017). 
Penelitian terkait sudah banyak dilakukan, karena itu penelitian ini berusaha melengkapi penelitian sebelumnya dari aspek proses dan berkembangnya Islam di Indonesia yang lebih umum. Penelitian terkait tersebut antara lain penelitian yang dilakukan Amin \& Ananda (2018), Syafrizal (2015), Husda (2017), Dalimunthe (2016), Baiti \& Razzaq (2014), Ghofur (2011), Syam (2018), dan Ghaffar (2015. Oleh karena itu penelitian ini bertujuan untuk mengetahui mengenai teori masuknya Islam dan proses Islamisai di Indonesia pola penyebaran Islam di Indonesia. Urgensi penelitian ini menjadi penting untuk melengkapi penelitian terdahulu dalam aspek sejarah Islam dan perkembangannya di Indonesia.

\section{Metode Penelitian}

Metode yang digunakan adalah metode penelitian kepustakaan. Penelitian ini membahas tentang teori-teori yang dikaji secara ulang. Objek penelitian ini adalah mengkaji tentang perjalanan Islam dan penyebaran Islam di Indonesia. Pengumpulan data dilakukan dengan menggunakan telaah dokumen sebagai strategi untuk mengumpulkan informasi. Sumber informasi peneliti lakukan melalui studi atas literatur kepustakaan. Teknis analisis data dilakukan melalui reduksi data, penyajian data, dan penarikan kesimpulan. Proses analisis data ini dilakukan berdasarkan informasi yang telah didapat melalui studi kepustakaan.

\section{Pembahasan}

Islam diperkirakan datang ke wilayah Indonesia abad ke-7 M dan berkembang secara lebih masif pada abad ke-13 M. Terkait kedatangan dan perkembangannya di Indonesia, proses Islamisasi berjalan dengan damai, walaupun terdapat penggunaan kekuatan oleh para penguasa muslim di Indonesia saat itu. Namun, mereka bias menerima Islam tanpa harus meninggalkan kepercayaan dan praktek keagamaan yang telah ada sebelumnya (Jannah, 2018). Proses Islamisasi di Nusantara dapat dipahami dari berbagai pendapat yang secara sejarah dapat dijelaskan dalam beberapa teori di bawah ini. 


\section{Teori-teori Tentang Munculnya Islam di Indonesia}

\section{Teori Gujarat}

Teori Gujarat dikemukakan oleh Snouck Hurgronje yang mengungkapkan bahwa kedatangan Islam dari Gujarat India. Ia memfokuskannya di sekitar Gujarat yang diidentikkan dengan beberapa hal yaitu; 1) tidak ada realitas yang mengungkapkan peran orang Arab dalam menyebarkan Islam ke Nusantara; 2) Antara Indonesia dan India cukup lama sudah memiliki hubungan perdagangan; 3) Enkripsi terkait Islam yang ditemukan di Sumatra adanya garis besar koneksi yang dijalin Sumatra dan Gujarat. W. F. Stutterheim, mengungkapkan bahwa perjalanan Islam ke Indonesia dimulai dari Gujarat pada abad ke13 M. Ditegaskan dengan adanya batu nisan para penguasa utama Kerajaan Samudra, khususnya Malik Al-Saleh yang wafat pada 1297 M (Mubarak, 2021)

\section{Teori Arab}

Teori Arab mengungkapkan kemunculan Islam ke Indonesia langsung dari Makkah, yang terjadi sekitar abad ke-7 M. Di Selat Malaka pada saat itu telah ramai oleh pedagang dari Arab. Mereka adalah Muslim, dalam prosesnya mereka tidak hanya berdagang, terutama rempah, mereka juga menyebarkan ajaran agama. Berita dari China juga mengabarkan ramainya pedagang Arab di Selat Malaka. Salah satu tokoh pendukung teori ini adalah Haji Abdul Malik Karim Amrullah (Hamka). Menurut beliau, pedagang yang datang kemungkinan adalah utusan Bani Umayyah. Ramainya perdagangan di Malaka bersamaan dengan 3 kerajaan besar, Dinasti Tang di Cina pada 618-907 M, Sriwijaya pada abad ke-7 M sampai dengan ke-14 M, Dinasti Umayyah pada 660-749 M. Jadi tidak menutup kemungkinan jika interaksi itu menjadi bagian penting dalam perjalanannya, selain berdagang itu juga misi dakwah. Bukti lain, di Barus Tapanuli Selatan ditemukan makam bertuliskan huruf $h a^{\prime}$ dan mim' dengan angka Arab 670 M (Mursan, 2018).

\section{Teori Persia}

Teori ini digagas oleh P. A. Hoesin Djajadiningrat yang menyatakan bahwa adanya kebudayaan yang sama antara kelompok Muslim Indonesia dan Persia. Sebagian dari persamaannya yaitu, pertama, amalan memuji pada 10 Muharram atau Asyuro, yakni hari suci Syiah dengan wafatnya Husain bin Ali. Kedua, antara pelajaran Syekh Siti Jenar dan 
pelajaran Sufi Iran al-Hallaj. Ketiga, pemanfaatan bahasa Persia dalam ejaan huruf arab, tanda bunyi harakat dalam pengajian (Rumahuru, 2018)

\section{Teori Cina}

Memang, peran orang Tionghoa dalam Islamisasi di Indonesia membutuhkan pertimbangan luar biasa. Banyaknya komponen budaya Tionghoa dalam komponen budaya Islam di Indonesia itu penting dipertimbangkan. Dalam hal ini "Teori Cina" dalam Islamisasi tidak bisa diabaikan (Husda, 2017). Berdasarkan pada banyaknya kebudayaan Cina yang terdapat pada kebudayaan dalam Islam di Indonesia (Amin, 2018). Banyak bentuk yang menyebutkan kemunculan Islam di Indonesia. Hal ini dapat dipandang sebagai tanda bahwa jalan masuk Islam ke Indonesia tidaklah terjadi pada satu waktu, bentuk, dan satu sebab (Solihin, 2017).

\section{Saluran Penyebaran Islam di Indonesia}

Islam merupakan agama mayoritas yang pengikutnya banyak ditemukan di Indonesia. Dalam proses penyebarannya memiliki banyak saluran yang berbeda. Saluran ini kemudian mempertegas proses dan berkembangnya Islam di Indonesia. Saluran-saluran tersebut sangat berkontribusi bagi meluasnya proses penyebaran Islam dan diterima dengan begitu mudah oleh masyarakat Indonesia. Proses tersebut dapat dijelaskan melalui beberapa saluran di bawah ini.

\section{Perdagangan}

Jalur ini adalah tahap awal yang mendasari kemunculan Islam di Indonesia dan terjadi sekitar abad ke-7 M hingga abad ke-16 M. Islam dibawa oleh pedagang muslim dengan jalur yang damai (Herniti, 2017). Pada waktu itu, terdapat banyak pedagang Muslim yang berdagang ke Indonesia hingga akhirnya mereka membentuk sebuah pemukiman. Di sini, mereka semua bekerja sama dan menyebarkan Islam. Di tempat inilah, mereka semua berinteraksi dan menyebarkan agama Islam. Para pedagang Muslim ini telah melaksanakan aktivitas ganda, aktivitas pokoknya sebagai pedagang dan disisi lain melaksanakan dakwah Islam.

Diawali dengan berdagang, selanjutnya kegiatan dakwah dilakukan lewat aktivitas pendidikan informal. Pada aktivitas pendidikan informal ini terjadi kontak personal antara 
pedagang yang merangkap sebagai mubaligh dengan masyarakat sekitar. Dari kontak personal tersebut terjadi komunikasi pendidikan. Pendidikan yang berjalan secara informal, tentu dalam hal ini pendidikan informal tidak membutuhkan sarana seperti yang dimiliki oleh lembaga formal. Tidak dibutuhkan tempat tertentu, tidak butuh kurikulum/silabus tidak memerlukan waktu tertentu, dapat berlangsung di mana dan kapan saja. Inti dari pendidikan informal itu adalah pergaulan antara pendidik (pedagang yang merangkap sebagai mubaligh) dan peserta didik, yakni masyarakat sekitar. Dalam hal ini pendidik (mubaligh) mentransferkan ilmu, nilai, dan keterampilan (Daulay, 2020). Proses ini kemudian membuat Islam diterima secara luas oleh masyarakat.

\section{Saluran Perkawinan}

Saluran perkawinan adalah salah satu proses Islamisasi yang tak terasa dan mudah untuk dilakukan. Hal ini dikarenakan ikatan pernikahan adalah ikatan yang lahir batin. Pernikahan dapat membentuk keluarga baru yang dapat menjadi pertanda perkembangan masyarakat yang besar dan dapat membentuk masyarakat muslim. Berdasarkan pandangan ekonomi, pedagang Muslim mendapatkan posisi yang lebih daripada masyarakat pribumi. Hal inilah yang menyebabkan khususnya para gadis terhormat, mereka ingin menjadi pasangan dari pedagang tersebut. Tetapi sebelum terjadinya pernikahan, maka wanita yang akan menikah tersebut terlebih dahulu harus mengucapkan syahadat sebagai bentuk penerimaan terhadap Islam (Binarto, 2020).

\section{Pendidikan}

Pesantren merupakan fondasi yang paling strategis dalam kemajuan Islam di Indonesia. Islamisasi melalui jalur pendidikan yaitu, dengan adanya pesantren ataupun pondok dan dilaksanakan oleh para guru agama, kyai, atau para ulama. Setelah mereka selesai menjalani pendidikan mereka akan keluar dari pesantren tersebut, dan mereka akan kembali ke daerah mereka atau mereka akan pergi ke suatu wilayah untuk menyebarkan dan untuk mengajarkan Islam (Mubarak, 2021). Proses ini merupakan jalur formal setelah Islam berkembang dan dapat dianggal sebagai jalur penegas setelah Islam dikenal secara luas di masyarakat Indonesia. 


\section{Tasawuf}

Tasawuf adalah ajaran yang berusaha mendekatkan umatnya kepada Allah SWT, Sang Pencipta. Tasawuf pada saat itu sangat efektif dan mampu mengadapatasi, mendiseminasi, dan mempercepat penyebaran Islam dalam masyarakat umumnya, dan dalam lingkungan kerajaan khususnya. Pendekatan sufistik dalam dakwah dinilai mampu mengakomodasi budaya (tata nilai, norma, tradisi, adat-istiadat, kearifan lokal) dan keyakinan lokal yang tumbuh sebelumnya. Daya adaptasi sufisme inilah yang melahirkan percepatan akulturasi antara Islam sebagai agama baru di satu pihak dengan Hindu, Buddha, dan indigenous faiths yang dianut dan berkembangan jauh sebelumnya (Jannah \& Hadi, 2018).

\section{Politik}

Politik merupakan metode penyebaran Islam dengan kekuasaan, beralihnya agama penguasa menjadi muslim sangat berpengaruh dan rakyat serta pendukungnya akan mengikuti dengan cepat. Penguasa juga dapat memengaruhi para penguasa lainnya untuk menganut agama Islam sehingga dalam hal ini Islam akan mengalami perkembangan yang sangat cepat (Susmihara, 2017). Berdasarkan pendapat para pakar sejarah menyatakan bahwa dalam penyebaran agama Islam di Indonesia tak terlepas dari banyaknya dukungan yang sangat kuat dari para penguasa (Gunawan, 2018).

\section{Seni dan Budaya}

Untuk penggunaan jalur kesenian sebagai media dalam berdakwah adalah sesuatu daya tarik yang lain. Menurut seorang sejarawan dari Persia yang tinggal di Malabar pada abad ke-15 M, yaitu Zainuddin al-Ma`bari. Ia menulis dalam sebuah bukunya yaitu, Tuhfat al-Mujahidin menyatakan bahwa banyak penduduk di India Selatan dan juga di Nusantara tertarik untuk memeluk agama Islam setelah mereka menyaksikan serta mendengar pembacaan mengenai riwayat kehidupan serta perjuangan Nabi Muhammad SAW yang disampaikan melalui sebuah bentuk syair dan dinyanyikan (Supriono, 2015). Syair diketahui sebelum Islam dating sudah ada terutama pada masyarakat Melayu. Hal ini membuka jalan bagi diterimanya Islam secara lebih cepat. 


\section{Kesimpulan}

Artikel ini membuktikan bahwa Islamisasi di Indonesia dilakukan dengan cara yang damai meskipun pada saat itu telah terjadi pemanfaatan kekuasaan oleh penguasa muslim di Indonesia. Mereka dapat menerima keberadaan Islam tanpa melepaskan keyakinan dan praktik keagamaan yang telah ada sebelumnya. Adapun kedatangan Islam ke Indonesia dapat dilihat dari beberapa teori yaitu; teori Gujarat, teori Arab, teori Persia, dan teori Cina. Teori tersebut tidak untuk meniadakan satu sama lain tetapi memperkuat bahwa Islam memang hadir di Indonesia dibawa dari berbagai wilayah. Untuk proses Islamisasinya dan penyebaran Islam yang ada di Indonesia dilakukan dengan beberapa jalur yaitu; jalur perdagangan, perkawinan, pendidikan, tasawuf, politik, serta seni dan budaya.

\section{Daftar Rujukan}

Amin, F., \& Ananda, R. A. (2018). Kedatangan dan Penyebaran Islam di Asia Tenggara: Telaah Teoritik tentang Proses Islamisasi Nusantara. Analisis: Jurnal Studi Keislaman, 18(2), 67-100.

Amrullah, A. (2015). Islam di Madura. Islamuna: Jurnal Studi Islam, 2(1), 56-69.

Astuti, H. J. P. (2017). Islam Nusantara: Sebuah Argumentasi Beragama dalam Bingkai Kultural. INJECT (Interdisciplinary Journal of Communication), 2(1), 27-52.

Baiti, R., \& Razzaq, A. (2014). Teori dan Proses Islamisasi di Indonesia. Wardah, 15(2), 133-145.

Binarto. (2020). Teori dan Proses Islamisasi di Indonesia. Prosiding Nasional, 3, 287-302.

Dalimunthe, D. (2016). Kajian Proses Islamisasi di Indonesia (Studi Pustaka). Jurnal Studi Agama dan Masyarakat, 12(1), 115-125.

Daulay, H. P., Dahlan, Z., Supriadi, S., Suridah, S., \& Hasanah, U. (2020). Proses Islamisasi di Indonesia: Tinjauan dari Berbagai Aspeknya. Jurnal Kajian Islam Kontemporer (JURKAM), 1(2), 41-48.

Ghaffar, N. A. (2015). Tasawuf dan Penyebaran Islam di Indonesia. Jurnal Rihlah, 3(1), 68-79.

Ghofur, A. (2011). Tela'ah kritis masuk dan berkembangnya Islam di Nusantara. Jurnal Ushuluddin, 17(2), 159-169.

Gunawan, S. (2018). Perkembangan Islam di Indonesia (Suatu Diskursus Tentang Awal Mula Islam Ke Nusantara). Yurisprudentia: Jurnal Hukum Ekonomi, 4(1), 13-29. 
Herniti, E. (2017). Islam dan Perkembangan Bahasa Melayu. Jurnal Lektur Keagamaan, 15(1), 81-96.

Husda, H. (2017). Islamisasi Nusantara (Analisis Terhadap Discursus Para Sejarawan). Jurnal Adabiya, 18(2), 17-29.

Jannah, M., Hadi, M. N., (2018). Islamisasi Nusantara dan Proses Pembentukan Masyarakat Muslim. Multicultural of Islamic Education, 2(1), 27-38.

Lestari, (2019). Islam Nusantara Corak Spiritualitas Pribumi. Jurnal Elkatarie: Jurnal Ilmu Pendidikan dan Sosial, 1(02), 28-41.

Mubarak, F. (2021). Pemikiran dan Peradaban Islam di Nusantara. OSF Preprints.

Mursan, S. (2018). Teori Kedatangan Islam dan Proses Islamisasi di Nusantara. DIRASAT, Jurnal Studi Islam dan Peradaban, 13(02), 55-65.

Rumahuru, Y. Z. (2018). Kontekstualisasi dalam Penyebaran Islam: Analisis Pola Pembentukan Islam di Nusantara. International Journal of Islamic Thought, 14, 123129.

Solihin, M. (2017). Memahami Kronologi Sejarah Penyebaran Islam di Nusantara. JOIES: Journal of Islamic Education Studies, 2(1), 87-102.

Supriono, I. A. (2015). Islam di Nusantara dan Transformasi Kebudayaan Melayu Indonesia. Madania: Jurnal Ilmu-Ilmu Keislaman, 5(2), 177-199.

Susmihara, S. (2017). Wali Songo dan Perkembangan Pendidikan Islam di Nusantara. Rihlah: Jurnal Sejarah dan Kebudayaan, 5(2), 151-168.

Syafrizal, A. (2015). Sejarah Islam Nusantara. Islamuna: Jurnal Studi Islam, 2(2), 235253.

Syam, S. (2018). Mengenal Islamisasi: Konflik dan Akomodasi (Kajian tentang Proses Penyebaran Islam Periode Awal di Nusantara). Al-Hikmah: Jurnal Dakwah dan Ilmu Komunikasi, 5(2), 76-84. 